\title{
触 New Disease Reports \\ First report of Tomato leaf curl New Delhi virus affecting zucchini squash in an important horticultural area of southern Italy
} S. Panno ${ }^{1,2}$, G. Iacono $^{1}$, M. Davino
${ }^{1}$, S. Marchione
Davino $^{3,6 *}$, V. Zappardo

${ }^{1}$ Department Di3A - University of Catania, Via S. Sofia 100, 95100 Catania, Italy; ${ }^{2}$ Euro-Mediterranean Institute of Science and Technology - IEMEST, Via Emerico Amari 123, 90139 Palermo, Italy; ${ }^{3}$ Osservatorio per le Malattie delle Piante, Via Uditore 15, 90145 Palermo, Italy; ${ }^{4}$ Department of Agriculture and Forest Science, University of Palermo, Viale delle Scienze Ed. 5, 90128 Palermo, Italy; ${ }^{5}$ Consiglio per la Ricerca in Agricoltura e I'Analisi dell'Economia Agraria - CREA, Centro di Ricerca per la Patologia Vegetale, Via Bertero 22, 00156 Roma, Italy; ${ }^{6}$ Institute for Sustainable Plant Protection National Research Council (IPSP-CNR), Strada delle Cacce 73, 10135 Torino, Italy

*E-mail: salvatore.davino@unipa.it

Received: 06 Dec 2105. Published: 01 Feb 2016. Keywords: begomovirus, Cucurbitaceae, emerging pathogen, ToLCNDV

Tomato leaf curl New Delhi virus (ToLCNDV) is a bipartite begomovirus (family Geminiviridae) which infects species in the families Cucurbitaceae and Solanaceae (Padidam et al., 1995; Mizutani et al., 2011). Begomoviruses are transmitted by the whitefly Bemisia tabaci in a persistent manner (Rosen et al., 2015). In October 2015, severe symptoms not previously reported by growers in the horticultural area of the Province of Trapani (Sicily, Italy) were observed on zucchini squash (Cucurbita pepo) in open fields. The symptoms included yellow mosaic, severe leaf curling, swelling of veins of young leaves, shortening of internodes, roughness of the skin of fruit and reduced fruit size; the symptoms were reminiscent of those caused by begomoviruses. Total DNA was extracted from young leaves of 22 plants by phenol/chloroform extraction and ethanol precipitation. PCR was performed with the A1F/A1R primer pair (Mizutani et al., 2011) for the DNA-A component and the pair described by Ruiz et al. (2015) for the DNA-B component to amplify a 1200-bp fragment of DNA-A and a $~ 890$ bp fragment of DNA-B, respectively. All 10 samples were positive by PCR with both primer pairs. No amplification products were obtained using primers specific for the monopartite begomoviruses Tomato yellow leaf curl virus and Tomato yellow leaf curl Sardinia virus (Davino et al., 2008). DAS-ELISA analysis for Cucumber mosaic virus, Papaya ring spot virus and Zucchini yellow mosaic virus (Loewe Phytodiagnostica, Germany) yielded negative results.

The amplification products of DNA-A and DNA-B components from three plants were purified using the UltraClean ${ }^{\circledR}$ PCR Clean-Up kit (Mo-Bio, USA) and the nucleotide sequences were determined in both orientations using an ABI 3130XL Genetic Analyzer (Life Technologies, USA). The sequences obtained from the three samples showed $99 \%$ identity. A Basic Local Alignment Search Tool (BLAST) analysis showed an identity $>99 \%$ with sequences of DNA-A and DNA-B of Tomato leaf curl New Delhi virus (ToLCNDV) isolates recently reported in Spain on zucchini (GenBank Accession Nos. KF749224 and KF749227) and tomato (KM977733 and KM977734). The DNA-A and DNA-B sequences of one sample were deposited in GenBank (KU145141 and KU145142).

Sicily is an important region for horticulture in the Mediterranean basin and Europe in general. With the possible opening of a free trade area in countries bordering the Mediterranean basin, Sicily may become a transit centre for flow of plant materials, potentially carrying new pathogens, between Europe and North Africa. To our knowledge, this is the first report of ToLCNDV in Italy, as well as the first identification of a bipartite begomovirus in Italian crops.

\section{References}

Davino S, Davino M, Accotto GP, 2008. A single-tube PCR assay for detecting viruses and their recombinants that cause tomato yellow leaf curl disease in the Mediterranean basin. Journal of Virological Methods 147, 93-98. http://dx.doi.org/10.1016/j.jviromet.2007.08.007

Juárez M, Tovar R, Fiallo-Olivé E, Aranda MA, Gosálvez B, Castillo P, Moriones E, Navas-Castillo J, 2014. First detection of Tomato leaf curl New Delhi virus infecting zucchini in Spain. Plant Disease 98, 857. http://dx.doi.org/10.1094/PDIS-10-13-1050-PDN

Mizutani T, Daryono BS, Ikegami M, Natsuaki KT, 2011. First report of Tomato leaf curl New Delhi virus infecting cucumber in central Java, Indonesia. Plant Disease 95, 1485. http://dx.doi.org/10.1094/PDIS-03-11-0196

Padidam M, Beachy RN, Fauquet CM, 1995. Tomato leaf curl geminivirus from India has a bipartite genome and coat protein is not essential for infectivity. Journal of General Virology 76, 25-35.

http://dx.doi.org/10.1099/0022-1317-76-1-25

Rosen R, Kanakala S, Kliot A, Pakkianathan BC, Farich BA, SantanaMagal N, Elimelech M, Kontsedalov S, Lebedev G, Cilia M, Ghanim M, 2015. Persistent, circulative transmission of begomoviruses by whitefly vectors. Current Opinion in Virology 15, 1-8.

http://dx.doi.org/10.1016/j.coviro.2015.06.008

Ruiz ML, Simón A, Velasco L, García MC, Janssen D, 2015. First report of Tomato leaf curl New Delhi virus infecting tomato in Spain. Plant Disease 99, 894. http://dx.doi.org/10.1094/PDIS-10-14-1072-PDN

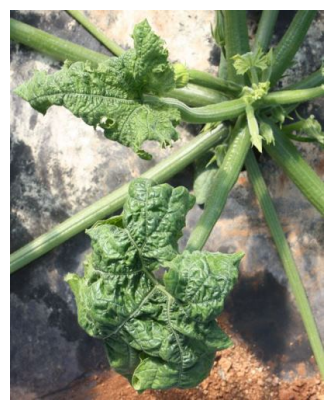

Figure 1

To cite this report: Panno S, lacono G, Davino M, Marchione S, Zappardo V, Bella P, Tomassoli L, Accotto GP, Davino S, 2016. First report of Tomato leaf curl New Delhi virus affecting zucchini squash in an important horticultural area of southern Italy. New Disease Reports 33, 6. http://dx.doi.org/10.5197/j.2044-0588.2016.033.006 